Bourguignon, François (2002): Inequality Among World Citizens I820-1992, in: American Economic Review, Vol.92, No. 4, pp. 727-744

Bradford, Colin/Linn, Johannes (2006): Global Governance Reform. Breaking the Stalemate, Washington, D.C.: Brookings Institutions Press

Collier, Paul (2007): The Bottom Billion: Why the Poorest Countries are Failing and What Can Be Done About It, Oxford: Oxford University Press

Dervis, Kemal / Ozer, Ceren (2005): A Better Globalization. Legitimacy, Governance and Reform,

Washington, D.C.: Center for Global Development

Easterly, William (2007): The White Man's Burden: Why the West's Efforts to Aid the Rest have

Done So Much Ill and So Little Good, Oxford: Oxford University Press

Sala-i-Martin, Xavier (2002): The Disturbing »Rise« of Global Income Inequality, NBER Working Paper, No. 8904, Cambridge, Mass.

The World Bank (ed.) (2006): World Development Report 2006: Equity and Development,

Washington, D.C.: The World Bank

Thompson, Michael / Ellis, Richard / Wildavsky, Aaron (1990): Cultural Theory, Boulder: Westview Press

United Nations (ed.) (1999): Human Development Report 1999, New York: United Nations

\title{
Wage Flexibility or Wage Coordination? Economic Policy Implications of the Wage-led Demand Regime in the Euro Area Engelbert Stockhammer*
}

Functional income distribution has shifted dramatically in the past 25 years. The wage share in the Euro area has fallen by ten percentage points since I98I.

This is the outcome of economic forces like globalization and technical change, but it has also been the result of deliberate policy pursued by the European Commission (EC) and by some national governments. Despite this drastic fall in wages relative to productivity unemployment has not decreased substantially. It is still higher than it was in 198I. The recommendations of the OECD and the EC to fight unemployment center around making labor markets more flexible. Wages should respond to national (or regional) conditions and increasing wage inequality is explicitly recommended. Wage moderation is regarded as golden way out of unemployment.

* Vienna University of Economics and Business Administration. I am grateful to Torsten Niechoj and Özlem Onaran for helpful comments. Support from FWF Project Nr. Pi8419-Gos is acknowledged. All errors are mine.

(C) INTERVENTION 5 (I), 2008, 54-62 
Figure I: Adjusted Wage Share and Unemployment in the Euro Area, I960-2006

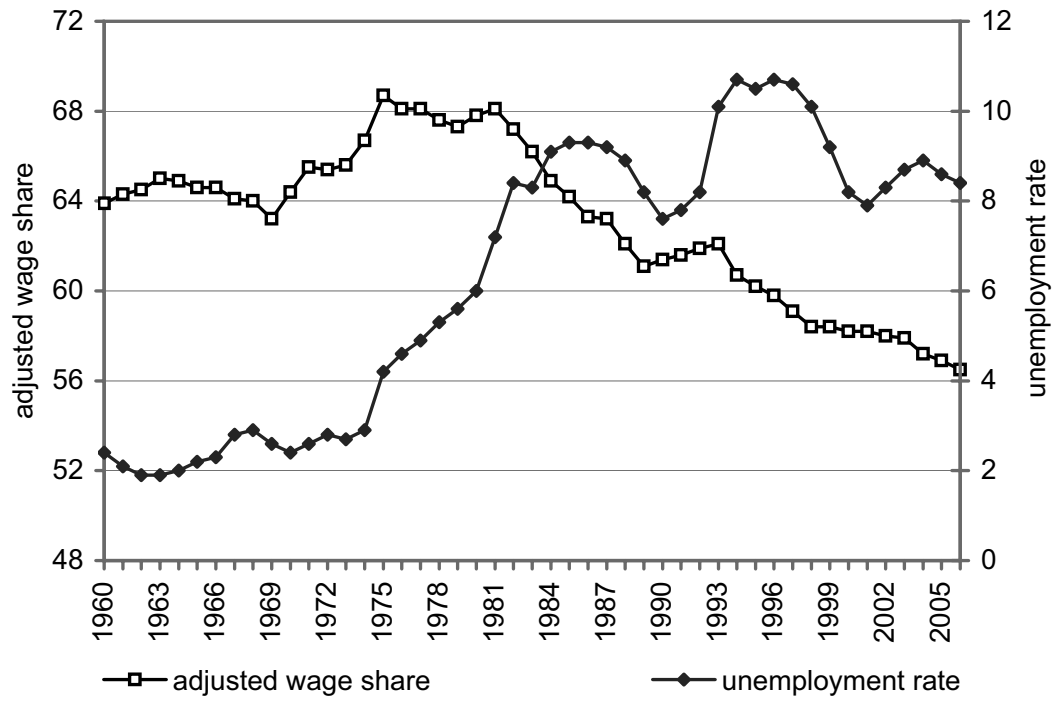

Source: AMECO

This paper takes a different view. Rather than reducing unemployment, wage competition has driven down wages and wage moderation has contributed to depressed domestic demand. As the policies of labor market flexibility have proven unable to cure unemployment and stabilize income distribution, an alternative strategy is needed. Wage coordination across countries and sectors could help take competitive pressure off the shoulders of wage bargainers and would thereby be an important precondition for a re-establishing of productivity-oriented wage policy. Indeed the following discussion of wage coordination

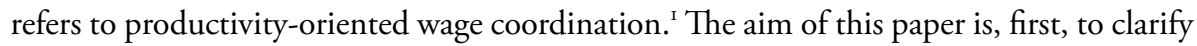
potential problems in the design of a coordinated productivity oriented wage policy at the European level. Second, the paper aims at highlighting that wage coordination is inconsistent with the present policy regime, which crucially relies on wage flexibility. A discussion of the political economy of wage coordination (Niechoj 2004, Schulten 2004) or its political feasibility is beyond the scope of this paper.

The paper first summarizes factors that have contributed to the decline in the wage share. Section two discusses demand effects of wage moderation. Section three discusses possible designs of wage coordination. Section four summarizes the present policy regime of the EU and the central role of wage flexibility therein. Section five outlines a policy regime for monetary and fiscal policy that could complement a regime of wage coordination.

I The analysis at time presupposes a coordination of wages on the national level. In fact European countries differ substantially in their bargaining structures. Indeed, for some countries an effective European coordination of wages would presuppose a national coordination of wages. 


\section{Economic and Economic Policy Factors in the Decline of the Wage Share}

Despite the substantial fall in the wage share in European countries mainstream economic institutions have, until recently, hardly discussed the issue. This has changed in the last year. Now the International Monetary Funds (IMF) admits that "globalization is one of several factors that have acted to reduce the share of income accruing to labor in advanced economies" (IMF 2007: I6I), while also highlighting the role of technological change. Similarly the OECD (2007) concludes that globalization (proxied by offshoring) has increased the vulnerability of workers.

While part of the decline in the wage share is probably due to exogenous factors, a substantial part is policy-induced. First, globalization itself is development that has been fostered by deregulation and liberalization, in particular capital account liberalization. For European countries, of course, the most important form of globalization is the Single Market. Economic integration has distributional effects. Beyond the standard Stolper-Samuelson effects (according to which the abundant factor, that is capital in the European case, will gain) there will also be bargaining effects. The mobile factor will benefit from liberalization because unlike the immobile factor it will take advantage of new opportunities (Rodrik 1997). As capital is more mobile than labor, the bargaining power of capital should increase, which will translate into an increase in the wage elasticities of labor demand. Indeed Hatzius (2000) and OECD (2007) find that labor demand in Europe has become more elastic.

Second, it has been a policy goal of the EU for many years to reduce the wage share. The Broad Economic Policy Guidelines for many years included that "real wage developments should be below the increase in productivity (EC 1995: 7, EC 1996: 5, EC 1997: 14). The most recent Guidelines recommend "real wage increases in line with the underlying rate of productivity growth over the medium term, « but are clearly more worried about wage growth rising above trend productivity than falling below (EC 2005: I5).

Third, there has been a series of national 'wage pacts` in the form of tripartite agreements that had wage moderation at their core, complemented by a policy package that made it more attractive to labor unions (Schulten 2004). While many of these wage pacts were part of efforts to meet the convergence criteria for the EMU, their significance is broader. Given that the present EU policy package restrains the use of fiscal and monetary policy for national aims, wage policy gains importance as a policy area. Effectively the present policy regime encourages wage competition between EU countries.

\section{Demand Effects of Changes in Functional Income Distribution}

So far we have been concerned with the causes of the falling wage share, now we will turn to its effects, in particular its effects on aggregate demand. A decline of the wage share will push the various components of aggregate demand in different directions. Firstly, it will likely have depressing effect on (private) consumption expenditures because wage income is typically associated with a higher consumption propensity than profit income. Secondly, it will have an expansionary effect on investment as profitability is rising. Thirdly, it will have 
a positive effect on net exports because the falling wage share is equivalent to a fall in unit labor costs which are a measure of price competitiveness. The overall or net effect is thus a priori indeterminate and depends on the specific size of the respective effects (Blecker I999, Bhaduri / Marglin I990). Table I summarizes the results of Stockhammer et al. (2007a), who estimated such a model for the Euro area.

Table I: Private Excess Demand ${ }^{I}$ (in Percentage Points of GDP) caused by a One-percentage-point Increase of the Wage Share

\begin{tabular}{lcc}
\hline & Effects in 2005 & Effects at mean levels \\
\hline Consumption & 0.43 & 0.37 \\
Investment & -0.07 & -0.07 \\
Domestic excess demand & 0.35 & 0.30 \\
Net exports & -0.16 & -0.11 \\
Private excess demand & 0.17 & 0.19 \\
\hline
\end{tabular}

I Private excess demand is the sum of the effects of a change in income distribution on consumption, investment, and net exports given the level of income.

Source: Based on Stockhammer et al. 2007a: table 7

They find that, with minor differences in the method of calculation, an increase in the wage share by one percentage point leads to an increase in (private excess) demand by o.I7 percent of GDP. This estimate is the lower bound of the actual effect as it does not account for second round effects such as the effect of increased demand on investment.

The size (and the sign) of this effect crucially depends on the openness of the economy. In other words, small open economies are likely to be profit-led, because foreign trade constitutes a much larger share of their GDP. ${ }^{2}$ Indeed, the parameter estimates of table I imply that the Euro area would switch from a wage-led to a profit-led demand regime at export and import shares of 23 percent to 30 percent. This has important policy implications for the Euro area. While demand is wage-led in the Euro area as a whole, this finding does not extend to individual Euro member states. The Euro area is a relatively closed economy, but its member states typically are rather open economies, with most of their trade conducted with other member states. It seems therefore likely that many EU member states exhibit (individually, not collectively) profit-led demand regimes. This is an example of a fallacy of composition. If so, European wage policy is in a prisoners' dilemma-type situation. While for each country it may be expansionary to exercise wage moderation (assuming constant wages abroad), wage moderation in all countries will have a contractionary effect. This is likely to generate a downward bias in wage settlements if wages are negotiated nationally.

2 See Bowles / Boyer (1995), Naastepad/Storm (2006), Hein/Vogel (2008) for studies on several countries. Stockhammer et al. (2007b) offer a careful treatment of the effects of globalization and find that Germany is in a wage-led demand regime. 


\section{Wage Coordination}

How could a system of European wage coordination look like? Productivity-oriented wage policy means that wages grow in line with inflation plus productivity growth. While it is straightforward to define productivity-oriented wage policy at the national level, this turns out to be more complicated at the European level. Equation (I) below illustrates this by decomposing the potential determinants of wages:

$$
\begin{aligned}
& w_{j}=\underbrace{b_{1} x^{j}+b_{2} x^{E U}}_{\text {productivity_indexation }}+\overbrace{b_{3} p^{j}+b_{4} p^{E U}+b_{5} p^{E C B}}^{\text {price_indexation }} \underbrace{-b_{6} u^{j}}_{\text {wage_flexiblity }}+ \\
& +\overbrace{b_{7}\left(W S^{E U}-W S^{j}\right)+b_{8}\left(W^{E U}-W^{j}\right)}^{\text {convergence_terms }}
\end{aligned}
$$

Where w represents nominal wage growth, w stands for growth of labor productivity, $\mathrm{p}$ is the inflation rate and $\mathrm{pEZB}$ the inflation target of the ECB, WS represents the wage share, $\mathrm{u}$ is the unemployment rate and W the level of wages; superscript EU stands for the EU, superscript $\mathrm{j}$ for individual countries.

This equation decomposes wage formation into effects related to productivity, effects related to inflation, effects related to unemployment (referred to as wage flexibility), and effects aimed at bringing about some kind of convergence within Europe. The equation allows to contrast different wage policies by giving different weights to the terms in the equation. For example the EC's aim to have a high degree of wage flexibility will be reflected in a high value for b6. The equation also highlights that wages can be linked to national or European values. Typically a given wage policy will ignore many of the possible determinants and many of the parameters will therefore be zero. For example a strictly national policy would refer only to national levels of inflation and productivity growth, therefore b2, b4 and bs would all be zero.

Productivity-oriented wage policy means that wages are fully linked to productivity and inflation. In a national system of productivity-oriented wage setting the relevant reference values for productivity and inflation, which means that bi and $b_{3}$ would be equal to one, whereas the other parameters are nil (or at least small). A European system of a coordinated productivity-oriented wage policy thus faces the question whether the reference values for inflation and productivity growth should refer are the national ones or the European ones, which will have different macro economic implications.

The European Trade Union Congress (ETUC) is the umbrella organization of trade unions in Europe, but it neither negiotiates wages itself nor does it have the power to impose its power on national (or sectoral) unions. It has endorsed a coordinated productivity-oriented wage policy. The ETUC recommends that wages grow with national productivity growth and the European inflation target of the European Central Bank (ECB) (Schulten 2004). Thus the wage formula of the ETUC would have bi und bs close to one and the other parameters nil. 
Such a strategy would 'freezer the relative unit labor costs, and hence the relative competitiveness, of the countries at the point in time when wage coordination started. If one also wanted to avoid current account imbalances across countries the relative unit labor costs (and consequently wage shares) would have to converge. This case is represented above as b7 being non-zero. A convergence of living standards on the other hand would require a convergence of wage levels (rather than wage shares, here: $b 7=0$ and $b 8>0){ }^{3}$

The aim of the ETUC is that wages should be oriented towards national productivity growth and the European inflation target of the ECB. This implies that national labor unions should have a strong eye on European developments, which reduces their scope of action with respect to national developments, which is why in the present policy regime unions will be reluctant to submit to such a regime. It would imply that Greek and Spanish workers would be compensated for the ECB inflation target rather than for their actual inflation rates (which are higher). Unsurprisingly such a system meets with resistance. With Eastern enlargement the tension will increase further. Assuming that Central and Eastern European economies will catch up, they are also likely to experience higher inflation rates than the EU average. Without further adjustment mechanism the wage shares would thus fall in these countries.

There is thus need to refine the ETUC's wage formula, though it can serve as a useful starting point. A pragmatic implementation might however mitigate the resulting problems. The much bigger problem is, however, not possible long-term divergences that are implied, but that wage coordination is inconsistent with present EU policy package.

\section{Wage Flexibility and the Present EU Policy Regime}

The macro-economic policy package currently in place in the Euro area is characterized by two features: first, there is a common currency and consequently a common monetary policy, which is conducted by an independent central bank that is almost exclusively concerned with price stability. Second, as EU fiscal policy is negligible quantitatively, fiscal policies are effecitively national and they are (asymmetrically) severely constrained by the European Stability and Growth Pact. In this setting wage policy plays a crucial role as a shock absorber for asymmetric as well as for symmetric shocks, which is why the ECB is consistently insisting that labor market flexibility is needed to ensure the proper functioning of the monetary union (Alsopp/Artis 2003). Indeed, with exchange rates gone, monetary policy centralized and fiscal policy constrained, one is almost tempted to say that wages are the only adjustment mechanism.

However, adjustment through wages is socially costly and it is not very effective. First, as wages are never perfectly flexible, an adjustment through wages usually requires substantial amounts of unemployment, which involves high social and personal costs. Second, if demand is wage-led in the EU, then flexible wages will send perverse signals in the case of adverse

3 Note that wage policy could aim at either a convergence of competitiveness or at a convergence of living standards. Only if structural policies (such as fiscal support for countries) were to ensure a convergence of productivity across countries, would the two be consistent. 
demand shocks. Rather than stimulating demand, falling wages (or more precisely falling wage shares) will dampen demand further. While it may work in one country, this will have negative (demand) externalities for other countries and it does not work for the EU as a whole.

Therefore the whole design of the policy package in Europe has to be modified. Monetary policy would have to get reoriented to output stabilization or fiscal policy would need more room (and coordination) for counter-cyclical policy, in particular in the face of asymmetric shocks.

\section{An Alternative Policy Regime}

A system of EU-wide wage coordination would thus have to be complemented by a policy regime that put shock absorbers other than wages in place. ${ }^{4}$ Exchange rate policy, which used to serve as a shock absorber, is irrevocably gone. Monetary policy can do little to address asymmetric developments within the EU. ${ }^{5}$ The main burden of adjustment would certainly lie with (national) fiscal policy, which would have to be more pro-active to address imbalances. An expanded system of (automatic) fiscal transfers from fast growing to slow growing regions would be an obvious system.

The present system puts an asymmetric burden on countries with a trade deficit in that the EC encourages only deficit, but not surplus countries to adjust. A system of wage coordination on the other hand would spread the burden more equally in that the surplus countries (assuming that they have a lower inflation rate) would automatically provide some of the adjustment via incorporating the (higher) European rather than the (lower) national inflation in its wage equation.

\section{Conclusion}

In fact, the dominant tendency is towards greater decentralization rather than centralization or coordination of wage bargaining (though not universally). Decentralization of collective bargaining has been a policy goal of major institutions like the OECD and the EC. Employer organizations have no interest in a centralization of bargaining. The divergence of unit labor costs across Europe suggests that unions have not been able or willing to coordinate wage effectively. ${ }^{6}$ They have often joined national regimes of wage moderation to stimulate exports in exchange for concessions in social policy and other areas.

4 The policy package is similar to that suggested by Hein / Truger (2004). Theoretical aspects of this policy mix are discussed (in a single country setting) by Hein/Stockhammer (2007). Arestis et al. (200I) and Huffschmid (2005) present proposals in a similar spirit.

5 A system of asset based reserve requirements could make some contribution by treating mortgages differently in countries with overheating property markets (Palley 2006).

6 Pointing to the decreased coefficient of variation of the growth rates of wages Marginson / Sisson (2004) argue that an implicit coordination of wages has taken place. However, this is a misleading indicator if some countries consistently have above average wage growth and some below average. And this has been the case since the introduction of the Euro. 
The economic performance resulting from this policy has been disappointing. Wage shares have declined substantially and unemployment remains high. Moreover, unit labor costs have been diverging since the introduction of the Euro. A system of productivityoriented coordinated wage bargaining would contribute to achieving the policy goals of an equitable distribution of income, to stabilize demand and to guarantee price stability. As regards the distribution of income, wage coordination could contribute to stabilizing the wage share as wage competition is reduced. As a stable (or rising) wage share has expansionary demand effects it would help maintaining the economy at full capacity. Finally, as long as wage coordination is productivity-oriented it is consistent with price stability. It would also help prevent price divergences across countries.

\section{References}

Alsopp, Christopher/Artis, Michael (2003): The Assessment: EMU, Four Years On, in: Oxford Review of Economic Policy, Vol. 19, No. I, pp. I-29

Arestis, Philipp/MacCauley, Kevin/Sawyer, Malcolm (200I): An Alternative Stability Pact for the European Union, in: Cambridge Journal of Economics, Vol. 25, No. I, pp. II3-I3O

Bhaduri, Amit/Marglin, Stephen (1990): Unemployment and the Real Wage: The Economic Basis for Contesting Political Ideologies, in: Cambridge Journal of Economics, Vol. I4, No. 4, 375-393

Blecker, Robert (1999): Kaleckian Macromodels for Open Economies, in: Deprez, Johan/Harvey, John (eds.), Foundations of International Economics: Post Keynesian Perspectives, London / New York: Routledge, pp. II6-I49

Bowles, Samuel / Boyer, Robert (1995): Wages, Aggregate Demand, and Employment in an Open Economy: An Empirical Investigation, in: Epstein, Gerald/Gintis, Herbert (eds.), Macroeconomic Policy After the Conservative Era. Studies in Investment, Saving and Finance, Cambridge: Cambridge University Press, pp. 143-171

EC (1995): Broad Economic Policy Guidelines, European Economy, No. 60

EC (1996): Broad Economic Policy Guidelines, European Economy, No. 62

EC (1997): Broad Economic Policy Guidelines, European Economy, No. 64

EC (2005): Integrated Guidelines 2005-2008 Including a Commission Recommendation on the Broad Economic Policy Guidelines, European Economy, No. 4

Hatzius, Jan (2000): Foreign Direct Investment and Factor Demand Elasticities, in: European Economic Review, Vol. 44, No. I, pp. 77-I43

Hein, Eckhard/Truger, Achim (2004): Macroeconomic Coordination as an Economic Policy Concept - Opportunities and Obstacles in the EMU, in: Hein, Eckhard / Niechoj, Torsten/Schulten, Thorsten/Truger, Achim (eds.), Macroeconomic Policy Coordination in Europe and the Role of the Trade Unions, Brussels: ETUI, pp. 19-67

Hein, Eckhard/Stockhammer, Engelbert (2007): Macroeconomic Policy Mix, Employment and Inflation in a Post-Keynesian Alternative to the New Consensus Model, Vienna University of Economics \& Business Administration Working Paper, No. IIo 
Hein, Eckhard / Vogel, Lena (2008): Distribution and Growth Reconsidered - Empirical Results for Austria, France, Germany, the Netherlands, the UK and the USA, in: Cambridge Journal of Economics (forthcoming)

Huffschmid, Jörg (2005): Economic Policy for a Social Europe: A Critique of Neo-liberalism and Proposals for Alternatives, Basingstoke: Palgrave Macmillan

IMF (2007): World Economic Outlook, Washington, D.C.: IMF

Marginson, Paul/Sisson, Keith (2004): European Integration and Industrial Relations. Multilevel Governance in the Making, Houndsmill: Palgrave MacMillan

Naastepad, C.W.M./Storm, Servaas (2006/07): OECD Demand Regimes (1960-2000), in: Journal of Post-Keynesian Economics, Vol. 29, No. 2, pp. 213-248

Niechoj, Torsten (2004): Keynesian Macro-coordination at EU level: Attractive to Trade Unions?, in: Hein, Eckhard / Niechoj, Torsten / Schulten, Thorsten / Truger, Achim (eds.), Macroeconomic Policy Coordination in Europe and the Role of the Trade Unions, Brussels: ETUI, pp. III-I62

OECD (2007): OECD Employment Outlook 2007, Paris: OECD

Palley, Thomas (2006): Currency Unions, the Phillips Curve, and Stabilization Policy: Some Suggestions for Europe, in: Intervention. Journal of Economics, Vol.3, No. 2, pp.35I370

Rodrik, Dani (1997): Has Globalization Gone too Far?, Washington: Institute for International Economics

Schulten, Thorsten (2004): Solidarische Lohnpolitik in Europa. Zur Politischen Ökonomie der Gewerkschaften, Hamburg: VSA

Stockhammer, Engelbert/Onaran, Özlem/Ederer, Stefan (2007a): Functional Income Distribution and Aggregate Demand in the Euro Area, Vienna University of Economics \& Business Administration Working Paper, No. IO2

Stockhammer, Engelbert/Hein, Eckhard/Grafl, Lukas (2007b): Globalization and the Effect of Functional Income Distribution on Demand in Germany, Vienna University of Economics \& Business Administration Working Paper, No. II4 